\title{
The Prospects of Azerbaijan to Enhance Military Interoperability with NATO
}

\section{Elman Nasirov and Khayal Iskandarov}

Institute of Political Studies of the Academy of Public Administration under the President of Azerbaijan

\begin{abstract}
After the end of the Cold War, NATO recognized the importance of extending far beyond its traditional borders in order to maintain peace and stability throughout Europe. The incorporation of new members into the Alliance came to the fore. In the light of this approach, cooperation with partner nations became an important area for discussion. Ensuring that partner forces could work together effectively was one of the main objectives and this, in turn, highlighted the term 'interoperability' once again. Thus, the evolution of interoperability between NATO and partner nations after the demise of Cold War is considered in this essay, its importance is underscored, the levels of interoperability are introduced and the feasibility of Azerbaijan's engagement in these levels is analyzed in this article. Different tools and mechanisms that the Alliance has launched over the last decades are scrutinized and useful recommendations are considered for Azerbaijan to enhance its military interoperability with NATO. From this perspective of interoperability, different successful models have been outlined as examples for Azerbaijan to follow.
\end{abstract}

Keywords: interoperability, NATO, security, cooperation, training, exercise.

\section{Introduction}

Having adopted a New Strategic Concept in 1991, NATO began to focus on the development of multinational force projection in order to adapt to the post-Cold War era and expand its capabilities for crisis management operations. In pursuit of future strategic goals NATO had to broaden and deepen cooperation with the 
countries beyond its traditional borders. Thus, the Alliance was in urgent need of partners that would be able to keep abreast of NATO requirements. This approach in turn required members, as well as partner forces, to work together for out-of-area operations. The first initiative, designed to encourage these nations to work together, was the Partnership for Peace (PfP) program which was launched in 1994. The ultimate goal of this program was, and still is, to support partners in their efforts to reform their national defense structures and to assist them in developing their national capabilities. If the partner nations that signed the framework of this program wanted their militaries to operate together, they would have to follow procedures mainly determined in Brussels by NATO Allies.

This initiative proved to be a very successful tool. The fledgling Republic of Azerbaijan was among those countries who joined the program with an expectation to integrate into the Alliance eventually. Shortly afterwards, the Alliance embarked upon the Partnership Planning and Review Process with the aim of promoting the development of the forces and capabilities of the partners that were best able to cooperate alongside NATO Allies in crisis response operations and other activities to maintain security and stability. It provided a structured approach for enhancing interoperability and the capabilities of partner forces that could be made available to the Alliance for multinational training, exercises and operations. ${ }^{1}$ This strategy continued over the ensuing years and the Alliance initiated new programs and mechanisms (such as the Operational Capabilities Concept (OCC), the Membership Action Plan (MAP), and the Individual Partnership Action Plans (IPAP)) for closer and deeper cooperation with its partners. The objective of NATO's partnerships, as stated in all three post-Cold War Strategic Concepts, is to safeguard security together. In the current Strategic Concept (2010), the three core tasks of NATO are collective defense, crisis management and cooperative security. Out of these, cooperative security is very much about partnerships. Thus, cooperative security is a broad task consisting of numerous elements. Fundamentally, it consists of three components: strengthening partnerships, contributing to arms control, non-proliferation and disarmament, and assisting potential new countries to prepare for NATO membership. An important sub-element of both strengthening partnerships and preparing new countries for potential membership is interoperability. ${ }^{2}$ In short, with the new NATO missions and engagement in operational theatres there has been a dramatic shift from a single nation fighting on its own, to coalitions where multinational units, down to the level of platoons, are working together.

1 Partnership for Peace Planning and Review Process, NATO Topics, last updated November 5, 2014, https://www.nato.int/cps/en/natohq/topics_68277.htm.

2 Stephen J. Maranian, "NATO interoperability: Sustaining Trust and Capacity within the Alliance," Research Paper 115 (Rome: Research Division, NATO Defense College, June 2015), https://www.files.ethz.ch/isn/192707/rp_115.pdf. 


\section{A strategy for Keeping Interoperability on Track}

The world is currently involved in a much more complicated security environment than it was decades ago. Thus, as an epicenter of global security NATO needs to become attuned to the challenges its member and partner nations are encountering. The implementation of the Alliance's grand strategy requires the continuous improvement of military effectiveness. In this regard interoperability is a sine qua non for the success of any operation/mission in coalition warfare. At the 2012 Chicago Summit, the Alliance embarked upon some new programs like Smart Defense (SD) and the Connected Forces Initiative (CFI). The rationale for launching these programs was, once again, the search for greater interoperability and coherence. ${ }^{3}$ The following declaration which was adopted in the Summit emphasized the importance of interoperability: "The Alliance's recent operational experiences also show that the ability of NATO forces to act together seamlessly and rapidly is critical to success. We will, therefore, ensure that the Alliance's forces remain well connected through expanded education, training and exercises." ${ }^{\prime 4}$ At this juncture, it is important to stress the various impacts that the lack of interoperability can have. First, it can endanger the successful implementation of operational missions. Second, it can have a major negative impact on resources and the logistical footprint, as it makes it difficult, or even impossible, to share spare parts, ammunition and fuel, and therefore, affects the efficiency of the force, in general. In certain areas, non-interoperability can have a dramatic impact, such as blue-on-blue fire or the unnecessary loss of life. It proves that enhancing interoperability increases the effectiveness of NATO operations and saves lives and resources. ${ }^{5}$ It is therefore in everyone's interest to cooperate and invest in order to achieve the highest level of interoperability and cooperation. In the Chicago Summit declaration, four of five references to interoperability dealt with extra-Alliance partnerships: Georgia, Ukraine, Mediterranean Dialogue nations and a general reference to partners attending the summit. ${ }^{6}$ This attitude, in turn, stimulated NATO's 'open door' and enlargement policy. In April 2013, when General Phil Breedlove took over U.S. European Command (EUCOM) he was asked, at his confirmation hearing, about the most im-

3 What is Transformation? An Introduction to Allied Command Transformation, with foreword by Lieutenant General Phil Jones, Chief of Staff (Norfolk, Allied Command Transformation, January 2015), http://www.ieee.es/Galerias/fichero/OtrasPublica ciones/Internacional/2015/NATO_Introduction_AlliedCommand_Transformation_Ja n2015.pdf.

4 Marcel-Petru Ivut and Florian Ianoşiu Hangan, "Interoperability between NATO and Partner States in the post-ISAF Period. Present and Perspectives," Romanian Military Thinking 11, no. 4 (October-December 2015): 116-124, http://smap.mapn.ro/gmr/ Engleza/Arhiva_pdf/2015/revista_4.pdf.

5 Florian Ciocan, "Perspectives on Interoperability Integration within NATO Defense Planning Process," Journal of Defense Resources Management 2, no. 2 (2011), 53-66, http://www.jodrm.eu/issues/volume2_issue2/06_ciocan.pdf.

6 Maranian, "NATO interoperability." 
portant lessons learned from 10 years of NATO operations in Afghanistan. Leading his list was the increased ability of U.S. and allied troops to literally fight and operate side by side: "First of all, NATO in general, and some of the partners, has become much more interoperable." General Breedlove went on to say that the risk of losing this interoperability was one of his key concerns in thinking about how the North Atlantic Alliance moves forward beyond Afghanistan. ${ }^{7}$

At the 2014 Wales Summit, the Alliance updated the concept for its NATO Response Force (NRF) which was created at the 2002 Prague Summit. But, it was after Russia occupied the Crimea in early 2014, when its significance really came to the fore. This Response Force is a technologically advanced, flexible, deployable, interoperable and sustainable force that includes land, sea, and air elements that will be available wherever it is needed. It is intended to serve as a vehicle for the transformation of allied nations' and partners' military structure and capabilities. ${ }^{8}$ A consideration of the last three declarations issued by the heads of NATO state and government shows that interoperability is mentioned sixteen times. The Wales Summit ${ }^{9}$ declaration gave it much more prominence than both Chicago $^{10}$ and Warsaw ${ }^{11}$ declarations, where it was mentioned only five and 13 times respectively. Therefore, it can be said that the 2014 Wales Summit established a basis for the enhancement of interoperability between NATO and partner nations by initiating invaluable programs and mechanisms.

By 2014, when NATO anticipated completing its operations in Afghanistan, allied militaries had been deployed together in combat and post conflict land, maritime, and air operations for more than 20 years. ${ }^{12}$ In order to implement this strategy, all stakeholders need to think and act coherently. It is about gaining and retaining a competitive advantage, a process which involves filling gaps and, in particular, those gaps which the changing environment threatens to create in the future. Recent destabilizing events around the globe, and within the EuroAtlantic region, have reinforced NATO's assessments of a future security envi-

7 John R. Deni, "Whose Responsibility is Interoperability?" Small Wars Journal, June 26, 2013, http://smallwarsjournal.com/jrnl/art/whose-responsibility-is-interoperability.

8 Juha Pyykönen, "Partners of NATO: How similar are Finland and Sweden within NATO cooperation?" FIIA Report 48 (Helsinki: Finish Institute of International Affairs ,2016), https://www.fiia.fi/en/publication/nordic-partners-of-nato.

9 Wales Summit Declaration, Issued by the Heads of State and Government participating in the meeting of the North Atlantic Council in Wales, NATO e-Library, Official Texts, September 5, 2014, www.nato.int/cps/en/natohq/official_texts_112964.htm.

10 Chicago Summit Declaration, Issued by the Heads of State and Government participating in the meeting of the North Atlantic Council in Chicago on 20 May 2012, last updated August 1, 2012, www.nato.int/cps/en/natohq/official_texts_87593.htm.

11 Warsaw Summit Communiqué, Issued by the Heads of State and Government participating in the meeting of the North Atlantic Council in Warsaw 8-9 July 2016, last updated March 29, 2017, www.nato.int/cps/en/natohq/official_texts_133169.htm.

12 Charles Barry, "Building Future Transatlantic Interoperability Around a Robust NATO Response Force," Transatlantic Current 7 (Washington, D.C.: National Defense University, Institute for National Strategic Studies, October 2012), quote on p. 1. 
ronment as being volatile, complex and uncertain. The political relevance of the Alliance and the military effectiveness of its forces will continue to be challenged by a combination of this highly dynamic, interconnected and ambiguous operating environment, together with a period of lasting fiscal austerity. ${ }^{13}$ In this regard, the constant improvement of military structures and capabilities of the Azerbaijan Republic has the utmost importance, because it entails enhancing its military effectiveness and interoperability with Allied forces.

The NATO Glossary of terms and definitions defines interoperability as "the ability of the forces of two or more nations to train, exercise, and operate effectively together in the execution of assigned missions and tasks." ${ }^{14}$ NATO's interoperability policy defines the term as the ability to act together coherently, effectively and efficiently to achieve tactical, operational and strategic objectives. Specifically, it enables forces, units or systems to operate together and allows them to share common doctrines and procedures, as well as each other's infrastructure and bases, and to be able to communicate with one another. Interoperability reduces duplication, enables the pooling of resources, and produces synergies among the 28 Allies, and, whenever possible, with partner countries. ${ }^{15}$ Therefore, interoperability occurs at various levels - strategic, operational, and tactical as well as technological. Because of these different levels and multiple dimensions, interoperability can be examined from the broadest available definition: "The ability of systems, units, or forces to provide services to and accept services from other systems, units, or forces, and to use the services so exchanged to enable them to operate effectively together."16

At a strategic level, interoperability is one of the essential factors contributing to the creation of a coalition of forces, thereby demonstrating a desire by the coalition members to act together against common threats as long as is necessary. At this level, interoperability focuses on harmonizing the global visions of the members' strategies, doctrines and force structures. At operational and tactical levels, interoperability refers mainly to how interoperable issues, that have been agreed at political and strategic levels, work together to support allied and partner states or members of a coalition in conducting crisis management, creating the environment to achieve the set of objectives, and winning the war. At the operational and tactical levels, interoperability depends on synchronization among allied and partner forces. In general, the benefits of achieving interoperability at operational and tactical levels are represented by the interchange of

13 "What is Transformation?" p. 3.

14 Ivut and Hangan, "Interoperability between NATO and partner states."

15 "Partnership Interoperability Initiative," NATO Topics, last updated June 7, 1017, https://www.nato.int/cps/en/natohq/topics_132726.htm.

16 "A Broad Definition of Interoperability," Chapter 2 in Myron Hura, Gary W. McLeod, Eric V. Larson, James Schneider, Dan Gonzales, Daniel M. Norton, Jody Jacobs, Kevin M. O'Connell, William Little, Richard Mesic, and Lewis Jamison, Interoperability: A Continuing Challenge in Coalition Air Operations (Santa Monica, CA: RAND Corporation, 2000), 7-15, www.rand.org/pubs/monograph_reports/MR1235.html. 
the coalition forces and units/subunits. ${ }^{17}$ At the technological level, the benefits of interoperability come, primarily, from their impacts at the operational and tactical levels in terms of enhancing fungibility and flexibility. This level focuses on "communications and computers but also involves the technical capabilities of systems and the resulting mission compatibility or incompatibility between the systems (hardware and software) and the data of coalition partners." ${ }^{18}$ Thus, it may be deduced that the qualities of interoperability at all levels are deployability, flexibility, sustainability, mobility, and survivability. This description makes interoperability one of the main requirements for effective operations.

In order to shed light on all levels of interoperability one can envisage an example of the way in which an air campaign could be conducted (as depicted in Figure 1). In this example the strategic level reviews the airspace policy and establishes airspace structures. The campaign level addresses operational planning and execution, as well as force planning according to NATO doctrines. The main element at this level is the political willingness to cooperate. Interoperability at the operational level occurs when strategic and tactical interoperability come together to manage crisis situations. The allocation of airspace takes place at the tactical level. Airspace structures determined at this level are disseminated to interested airspace stakeholders. The technological level focuses on the technical capabilities of the systems and data of coalition partners to respond in similar way to a particular situation.

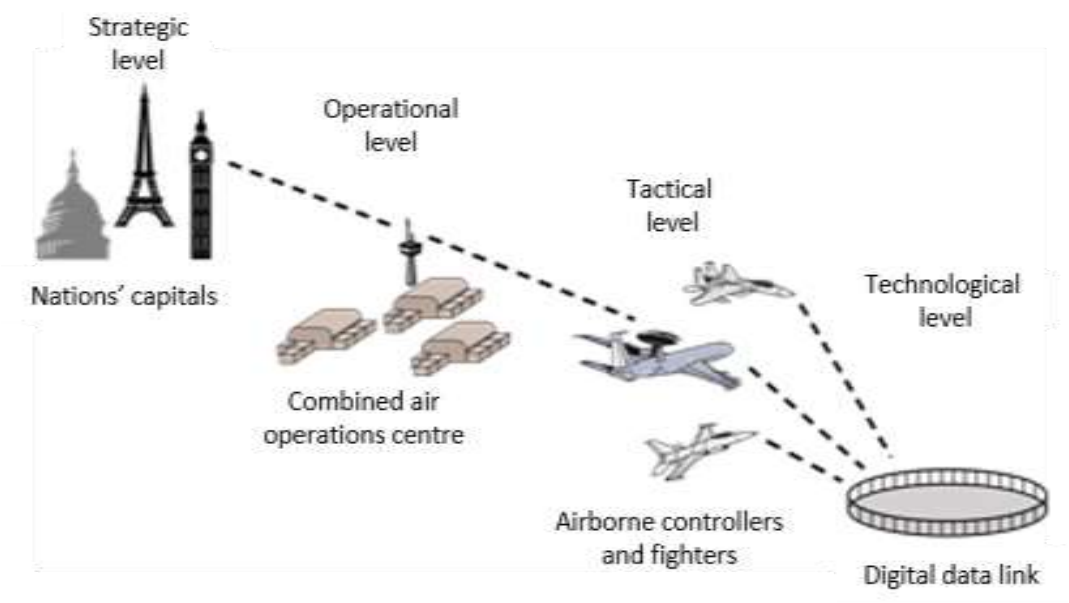

Figure 1: Interoperability at four levels - Case of air campaign. ${ }^{19}$

17 Ivut and Hangan, "Interoperability between NATO and Partner States."

18 "A Broad Definition of Interoperability," p. 13.

19 "A Broad Definition of Interoperability," p. 9. 
Achieving interoperability is a constant necessity at all levels. In NATO member states it is achieved by implementing agreed standards. As for the relations with partner states, achieving a high level of interoperability is a crucial factor considering the joint participation in NATO-led operations/missions. ${ }^{20}$ While NATO members are engaged at every level, partner nations are not involved at the strategic level. Parenthetically, the Alliance develops partnerships at different levels and it is up to the partner nation to choose the level at which it wishes to engage in order to strengthen and extend their peace and stability. Since Azerbaijan has not articulated a desire for full membership, a concrete way to achieve interoperability from a military perspective is to benefit from the tools and mechanisms regarding education and training that the Alliance has launched over the past years. In fact, these tools are a valuable means by which to improve interoperability and capabilities at all levels. Having capitalized on these opportunities, military forces of some partner nations (e.g. Austria, Finland and Sweden) have reached a high level of interoperability as a result of years of participation in joint training and exercises at the first three levels. Interoperability is not necessarily a political decision, it is more often a technical one. Therefore, there would appear to be no hindrances to the Azerbaijan Armed Forces being fully interoperable with NATO.

Interoperability does not, necessarily, mean that allied or partner states should have or should purchase common military equipment. It is as much, or more, about human teamwork than it is about compatible machines and processes. What is especially important is the ability to use the existing equipment by sharing facilities, and so being capable of interacting, connecting, communicating and exchanging information and services with similar equipment from another states inventory. ${ }^{21}$ Here, it is necessary to mention that the Azerbaijan Armed Forces have made giant strides by utilizing NATO's Partnership Staff Element (PSE) concept and its Defense Education Enhancement Program (DEEP). The PSE concept creates possibilities for Azerbaijan to deploy its officers within various NATO headquarters and commands to gain experience and knowledge by working side-by-side with Allies in the same headquarters and offices. Azerbaijan utilizes this instrument effectively and has sent more than 20 officers to various PSE posts since 2002, making it one of the biggest partner staff contributors among the PfP countries. ${ }^{22}$ After completing their missions, these officers are appointed to various leading positions where they may contribute to the enhancement of the relations between NATO and Azerbaijan. Having identified the needs in the military domain, Azerbaijan has begun to utilize widely the NATO expert advice available through the DEEP Program in order to upgrade its mili-

20 Ivut and Hangan, "Interoperability between NATO and Partner States."

21 Ivut and Hangan, "Interoperability between NATO and Partner States."

22 Azerbaijan - NATO partnership (Brussels: Mission of Azerbaijan to NATO, 2014), http://nato-pfp.mfa.gov.az/files/file/broch_AZE-OTAN_LR.pdf. 
tary education system with the purpose of becoming intellectually interoperable with the Alliance.

Given the above-mentioned aspects it can be deduced that interoperability encompasses the following areas ${ }^{23}$ :

1. the ability of forces from different nations to work effectively together

2. the effectiveness of the combined military organizational structure

3. the degree of similarity of technical capabilities of the forces from different nations.

According to an action plan approved by NATO Defense ministers, interoperability has three dimensions ${ }^{24}$ :

1. technical (hardware and systems)

2. procedural (doctrine and procedures)

3. human (language, terminology and training).

On the other hand, the mechanisms that support the achievement of interoperability are: the effective implementation of allied agreed standards (STANAGs), doctrine and tactics; joint training; the participation in NATO/multinational exercises; the application of NATO policy related to lessons learned; and the conduct of demonstrations and tests. According to the NATO Strategic Concept 2010, partnerships with third countries "can make a concrete contribution to enhancing international security, to defending the values on which the Alliance is based, to NATO's operations and to preparing interested nations for membership of NATO." 25

Interoperability in coalition warfare is at the core of U.S. defense policy and military doctrine. The January 2012 Defense Strategic Guidance, the most recent top-level Department of Defense (DOD) strategy document, emphasizes sixty times the importance of allies and partners in its brief eight pages. The latest version of the military's capstone doctrinal publication refers to interoperability 87 times in just 200 pages. $^{26}$

At the 2012 NATO Summit in Chicago, NATO committed itself to further strengthening and deepening its partnerships. This was reaffirmed at the 2014 Wales Summit when it launched the Partnership Interoperability Initiative (PII) to maintain and deepen the interoperability that has been developed with partners during NATO-led operations and missions over the last decades. Once again, the PII underlined the importance of interoperability for all its partnerships and proposed new means to deepen cooperation with those partners that wished to be interoperable with NATO. As NATO's Deputy Secretary Gen-

\footnotetext{
23 "A Broad Definition of Interoperability."

24 "Interoperability: Connecting NATO Forces," NATO Topics, last updated June 6, 2017, https://www.nato.int/cps/ic/natohq/topics_84112.htm.

25 Ivut and Hangan, "Interoperability between NATO and Partner States."

26 Barry, "Building Future Transatlantic Interoperability."
} 
eral Alexander Vershbow emphasized: "This is the first standing consultative forum dedicated to interoperability, and by far the greatest opportunity for cooperation and dialogue for those who wish to be an enhanced opportunity partner." ${ }^{27}$ Included in the PII is the "Interoperability Platform" of 25 selected partners and the tailor-made "Enhanced Opportunities" for deeper cooperation with five specific partners (Australia, Finland, Georgia, Jordan and Sweden). ${ }^{28}$ This initiative provides increased capacity to cooperate with partners to counter security threats by:

1. interrelating all existing interoperability mechanisms and programs

2. supporting partners that wish to become interoperable

3. providing partners that significantly contribute to the Alliance with increased opportunities, and

4. developing, maintaining, diversifying and increasing a pool of forces and capabilities belonging to partner states, which are certified and ready to contribute to future NATO operations or to the NRF. ${ }^{29}$

The second initiative, which was endorsed at the Wales Summit to reinforce the Alliance's commitment to the core task of cooperative security, is the Defense and related security Capacity Building (DCB) Initiative. It focuses on helping partners to provide their own security by strengthening their defense and related security capacity..$^{30}$ In this regard the Partnership for Peace Planning and Review Process, the Operation Capabilities Concept and the Military Training and Exercise Partnership are the main tools by which to promote the interoperability and capabilities of the forces of partner nations. The Alliance has recently developed an Individually Tailored Roadmap Capstone Concept that should simplify existing partnership programs and improve cooperation by increasing shared situational awareness and trust. Pilot projects that include cyber-defense aspects have been launched with Finland, Georgia and Jordan. Another model of how NATO and coalition partners have worked together to improve interoperability and information sharing in operations, exercises and training events is NATO's Federated Mission Networking. This framework includes policy, processes, procedures, standards and physical components such as static and deployed networks, services and supporting infrastructures. Partners will be engaged also in the areas of early warning, prevention, and analysis of cyber threats. ${ }^{31}$

27 "Partnership Interoperability Initiative."

28 "Partnership Interoperability Initiative."

29 Ivut and Hangan, "Interoperability between NATO and Partner States."

30 "Partnership Tools," NATO Topics, last updated June 24, 2016, www.nato.int/ cps/en/natohq/topics_80925.htm.

31 Piret Pernik and Tomas Jermalavičius, "Resilience as Part of NATO's Strategy: Deterrence by Denial and Cyber Defense," in Forward Resilience: Protecting Society in an Interconnected World, ed. Daniel S. Hamilton (Washington, D.C.: Center for Transatlantic Relations, Paul H. Nitze School of Advanced International Studies, Johns Hopkins 
NATO militaries have achieved a high level of interoperability through decades of joint planning, training and exercises. Member countries have put this interoperability into practice and developed it further during joint operations and missions. These operations have also enabled partner countries to improve their interoperability with the Alliance. ${ }^{32}$ The International Security Assistance Force is the best example of this, both in terms of the benefits arising from achieving a high level of interoperability between NATO and partner states and the need to maintain the achieved level. ${ }^{33}$ If maintaining, and even developing, the achieved level of interoperability with partner nations is a priority for NATO, then Azerbaijan's aspiration of much deeper cooperation with the Alliance is a realistic goal.

\section{Conclusion}

In order to be interoperable with NATO forces, a state is required to have qualified military capabilities. Azerbaijan has been developing its military capabilities since it achieved independence from the USSR. Azerbaijan is an enthusiastic partner of NATO. However, there is still a lot of work to be done in order to enhance its military interoperability with NATO. Azerbaijan needs to go beyond achieving minimum interoperability and reach a higher stage of integration. Taking into account all of the four levels of interoperability introduced in this article, Azerbaijan is, arguably, actively engaged in the first three levels (technological, tactical and operational levels). In order to achieve all of these goals Azerbaijan will need to enhance its national capabilities for crisis response operations in order to be a capable, willing and reliable partner in a crisis. Thus, more demanding exercises and training are welcomed by Azerbaijan, as multinational exercises verify interoperability in an effective manner. The bottom line is that the more a partner invests in cooperation, the more it benefits from it. PARP remains one of the most effective mechanisms for Azerbaijan in the field of defense and force planning. The Operational Capabilities Concept has to be utilized widely to ensure the required level of armed forces interoperability.

In order to increase interoperability with Western forces, Azerbaijan may benefit from NATO through obtaining advice in areas such as defense institution building, cyber defense, logistics, and standardization. NATO, in turn, could develop more robust assistance and engagement programs for Azerbaijan considering its vulnerability and susceptibility to neighboring aggression. DEEP is an invaluable tool to develop educational institutions in the defense sector and to make Azerbaijani military personnel intellectually interoperable with NATO's.

As a part of the "Interoperability Platform" Azerbaijan has recognized the importance of working together with NATO and may benefit from a more tailor-

\footnotetext{
University, 2016), 99-112, https://archive.transatlanticrelations.org/publication/ forward-resilience-protecting-society-interconnected-world/.

32 "Interoperability: Connecting NATO Forces."

33 Ivut and Hangan, "Interoperability between NATO and Partner States."
} 
made relationship, such as "Enhanced Opportunities" to maintain an optimal level of interoperability. In this way, the Alliance may create additional tailored programs based on the individual needs of Azerbaijan. In addition to the above programs, Azerbaijan could ask for a defense and related security capacity building package in order to strengthen its defense and related security through education and training. The NATO Response Force is the central platform for sustaining interoperability and Azerbaijan could easily benefit from the Connected Forces Initiative concept for the enhanced training of its troops and, with the use of modern technology, to facilitate interoperability and integration of the required capabilities. Also, by deploying the minimum level required by the OCC evaluators for potential operations, Azerbaijan could join NRF exercises with other designated forces since it is the most visible instrument for the certification of interoperability capabilities between NATO and Azerbaijan. Finally, it is important to stress that foreign language training is a prerequisite for the whole gamut of interoperability-related activities. The primary focus is, of course, on English as the language of the NATO integrated military structure. Thus, the Foreign Language and Partnership Center functions under the aegis of the War College, with the purpose of imparting training in different foreign languages to the personnel of the Armed Forces. By enabling Azerbaijani military personnel to communicate in English at a reasonable level of proficiency (STANAG levels 2-3), they are provided with an opportunity to learn NATO tactics in the military domain.

\section{About the authors}

Prof. Elman Nasirov is Doctor in political sciences and Director of the Institute of Political Studies of the Academy of Public Administration under the President of Azerbaijan. He serves also as member of parliament of the Republic of Azerbaijan.

Khayal Iskandarov is Chief of the editorial section of the War College of the Armed Forces, Republic of Azerbaijan. He holds a Master degree in military sciences and is currently pursuing a PhD degree in military sciences and national security.E-mail:xayal1333@gmail.com. 